\title{
AZ INTEGRÁLT ÉS AZ INKLUZÍV NEVELÉS HATÁSA A PEDAGÓGUSKÉPZÉS EGYES TERÜLETEIN
}

\author{
Papp Gabriella ${ }^{*}$ - Schiffer Csilla ${ }^{* *}$ \\ * az Eötvös Loránd Tudományegyetem Bárczi Gusztáv Gyógypedagógiai Karának \\ föiskolai tanára \\ papp.gabriella@barczi.elte.hu \\ ** az Eötvös Loránd Tudományegyetem Bárczi Gusztáv Gyógypedagógiai Karának \\ föiskolai adjunktusa \\ schiffer.csilla@barczi.elte.hu
}

\begin{abstract}
Az integrált nevelés után immár az inkluziv nevelés szociál- és oktatáspolitikai fogalmával ismerkedik a pedagógusképzés. Ahogy e két fogalom alapvetöen különbözö szemléletet és gyakorlatot ír le, úgy különbözö változási folyamatok indultak el „,nevükben” a gyógypedagógus-, a tanitó- és a tanárképzés területén. Az egymás munkáját kiegészitö pedagógusképzési szakterületek inkluziv szemléletü megújulása olyan hosszú távú folyamat, amelyekben jelentös eredményeket ért el a magyar pedagógusképzés, de még komoly kihivásokkal is küzd e terület. A tanulmány már müködö és még elöttünk álló innovativ folyamatokat mutat be a pedagógusképzés megújitása terén.
\end{abstract}

\section{Az integrált neveléstől az inkluzív nevelésig}

Az integráció és az inklúzió fogalmára is igaz, hogy alkalmazása során folyamatosan alakuló, változó jelentéstartalommal bír. Mindkettő a társadalmak összetartó erejét fokozni kívánó értéktételezéseken alapul, de mindkettőt a társadalom számos csoportja, eleme értelmezi a maga belső és sajátos világában, így formálja jelentését és nevelési nézőpontját.

$A z$ integrált nevelést a pszichológia és a gyógypedagógia oldaláról Lányiné Engelmayer Ágnes $(1987,933$.) elsősorban „az eltérő képességü és fejlettségü gyermekek integrált, közös rendszerben történő nevelésének gondolata"-ként értelmezte. Az integrált nevelés, az együttnevelés lényegi eleme, hogy az egyes gyermek felől közelíti meg az iskoláztatás kérdését, az ő beilleszkedésének folyamatát jelöli, amelyhez a gyermek pedagógiai segítséget (fejlesztést) is kaphat. Az integráció fogalmát hazánkban az ezredfordulón az „eltérő képességü és fejlettségü" tanulókon túl kiterjesztették a roma (Réthy, 2004; Kalocsainé és Varga, 2005), majd a bevándorló gyermekek oktatására is (Simon, 2005). Az integráció fogalmának megértéséhez a szegregáció fogalmának értelmezése is szükséges. A szó elkülönülést, elkülönítést jelent magyarul. Önmagában az elkülönülés nem minősített, 
nem értéktelített tevékenység, ugyanakkor az elkülönítés fogalom szociológiai értelmezésében együtt jár az elkülönített csoport lényeges egyenlőtlenségének megjelenésével (Andorka, 1997). Az „oktatási szegregáció” fogalma a tartalmat az iskola világában értelmezi. A lakóhelyi elkülönülés, illetve a többségi társadalom kirekesztő magatartásának eredményeként a roma tanulók elkülönített oktatása esetében használja (Havas, Kemény és Liskó, 2002; Lannert, 2004). Az elkülönítés az eltérő tantervü, iskolákban folyik. Ezek az intézmények gyógypedagógiai iskolák, így a roma tanulók enyhén értelmi fogyatékosságának a kérdése áll a kritikák középpontjában. A gyógypedagógiai iskoláztatás azonban tágabb, mint az enyhén értelmi fogyatékos tanulók (tanulásban akadályozott) ellátása, hiszen az intellektuális képességzavar, a beszédfogyatékosság, a különböző nyelvi zavarok, a mozgáskorlátozottság, látás-, hallássérülés, autizmus spektrumzavar stb. esetei is különleges gondozást igényelnek. Elsődlegesen nem a kirekesztés céljából jött létre a gyógypedagógiai ellátás, hanem az ellátatlan, intézményi megsegítést sosem kapottak, az „elesettek" megsegítésére. Ilyen értelemben külön, a meglévő intézményrendszer mellett alakult, változott a gyógypedagógiai ellátás tartalma, intézményei stb., mindig reagálva a társadalmi szükségletekre. Ebben az értelemben az elkülönítés, szegregáció nem jelenti az egyenlőtlenségeket, az alacsonyabb szolgáltatást, rosszabb minőséget. Az integráció kifejezés tehát a korábban elkülönült részek összeillesztéseként értelmezhető. Ha nincs először szegregáció, akkor nincs utána integráció. A teljes „egész” szempontjából ilyen értelemben kiegészítik egymást. A roma tanulók esetében azonban éppen az integráció-szegregáció ellentétpárban értelmezhetö. Mivel a szegregáció fogalom értelmezése több elemü, a gyógypedagógia fenti, tág értelmezése miatt javasolt inkább a „külön gyógypedagógiai” kifejezés használata.

Ahogy az integráció fogalompárja a szegregáció, úgy az inklúzió (befogadás) dimenziójának másik pólusán annak definíciói szerint az exklúzió (kirekesztés) található. Az inkluzív nevelés eszménye nemzetközi szervezetek támogatásával került globális szinten napirendre (Pijl et al., 1997), jelentős hatást gyakorolva a szociál- és oktatáspolitikák világára. Megvalósításának lépéseit először az UNESCO Salamancai nyilatkozatában és cselekvési tervezetében (1994) jelölték ki, amelyet azonban ugyanezen szervezet 2005-ben az irányelvek szintjén kiegészített.

$A z$ inklúzió az UNESCO irányelveinek megfelelően a sokféleség örömmel fogadását jelenti, minden tanuló érdekének szem előtt tartását, az oktatáshoz való egyenlő hozzáférést, azon gyerekek bevonását, akik az iskolában kirekesztettnek érezhetik magukat, valamint meghatározott ellátás biztosítását a gyermekek néhány csoportja számára, kirekesztés nélkül. Az inklúzió nem csupán a gyógypedagógia (special education) reformját jelenti, hanem az oktatási rendszer átalakítását is. Nem kizárólag a másságra irányítja a figyelmet, hanem minden tanuló számára javítani szeretné az oktatás minőségét. Nem jelent elkülönített iskoláztatást, a szükséges többlettámogatást a többségi iskolákban biztosítja. Nem kizárólag a fogyatékos gyermekek 
szükségleteire koncentrál, és fontos, hogy nem más gyermekek rovására kívánja az egyes gyermekek szükségleteit figyelembe venni (UNESCO, 2005).

Az inklúzió szemléletének megfelelően a gyermek egyéni (biológiai, képességbeli) sajátosságainak hangsúlyozása mellett egyre inkább előtérbe kerülnek a társadalmi és pedagógiai szempontok. A szaktudomány, a gyógypedagógia szerves fejlődése során a fogyatékosság orvosi-pszichológiai modellje a szociális modellel egészült ki, amely szerint nem kizárólag a gyerekben rejlik az akadály, hanem a szocializációt befolyásoló környezetben, tágabban magában a társadalomban. Az utóbbinak részeként pedig az oktatási rendszerben találhatók meg azok a szerkezetek és folyamatok, amelyek kiváltják, felerősítik a kirekesztést, akadályozzák a befogadást. Az oktatásirányítás alapvető feladata tehát, hogy iskolai szinten is minél szélesebb körben és minél eredményesebben haladjon az inklúzió akadályainak lebontása (Csányi, 2000).

Az inkluzív nevelés értelmezői és megvalósítói - bár alapvetőnek tartják az egyes gyermekek szükségleteinek figyelembevételét - de a megoldás során nem az egyes gyermekből, hanem a társadalmi folyamatokból, a szervezetekből, az iskoláztatás rendszeréből és intézményeiből indulnak ki. Az inklúzió egy oktatási rendszer, egy oktatási intézmény jellemzője, hiszen a megértés, a befogadás, az együttélés csak szociális térben történhet meg. Az inkluzív nevelés kapcsán nem kizárólag az egyes „beilleszkedni nem tudó” gyermekek sajátosságait elemzik, inkább az (oktatási) intézményt vizsgálják, hogy valóban képes-e minden gyermek befogadására és differenciált oktatására ${ }^{1}$. Az exklúziót, a kirekesztést pedig nem a gyermek, hanem az iskola problémájaként, kudarcaként értelmezik (Ainscow, 1996; Hinz, 2002).

E nevelési koncepció elterjedése érdekében az ENSZ nemzetközi politikai befolyásával nyomást gyakorol az európai és a nemzeti szakpolitikákra is. Ennek hatása az Európai Unióhoz való csatlakozásunk óta egyre határozottabb tetten érhető a hazai szociál- és oktatáspolitikában, sőt a neveléstudomány és a gyógypedagógia egyes területein is érezhető megtermékenyítő hatása.

\section{Az inkluzív nevelés mint a neveléstudomány és a gyógypedagógia megújulásának, valamint együttmüködésének ösztönzője}

Az integrált nevelés kapcsán alapvető tapasztalat, hogy általa „új együttmüködési formák alakulnak ki a pedagógusok és a gyógypedagógusok között, ennek következtében a pedagógusképzésben és a munkahelyi alkalmazásban elkülönített kompetenciák bizonyos nevelési helyzetekben összetalálkoznak" (Mesterházi, 1998a, 12. o.). Az együttnevelés hazai tapasztalatai kapcsán Illyés Sándor (2001) arról írt, hogy a résztvevők mindegyike számára újdonságértékkel bírt az integráció elméle-

\footnotetext{
${ }^{1}$ Az adaptív oktatásról és a differenciálásról lásd e számunkban Gaskó Krisztina, Kálmán Orsolya, Mészáros György és Rapos Nóra tanulmányát.
} 
te és gyakorlata: hiszen ha a többségi iskola pedagógusai ismerték volna az integrációt, nem kérték volna a fogyatékos gyermekek gyógypedagógiai intézményekbe történő áthelyezését, de a gyógypedagógia számára is új volt, mert az ép és fogyatékos tanulók együttnevelésével soha nem foglalkozott.

A gyakorlati együttmüködési formák mellett e két terület elméletének viszonya is kérdések kereszttüzébe került. Rödler például egy „általános különpedagógia” kidolgozását tekintette megoldásnak, amely egy kevésbé speciális, inkább egy különösen differenciáló, integratív, hatékony általános pedagógia (1993). Megoldásmódja tehát a gyógypedagógia általános elméletének megerósítésére épít. Dreher (1997) koncepciójában a súlyosan halmozottan fogyatékosok pedagógiájának nevelésfilozófiai és neveléselméleti alapjai válhatnának egy valóban általános pedagógia központi elemeivé, amelyek a nevelési gyakorlat számára egészen új nevelési struktúrákat, tartalmakat és módszereket tárhatnának fel. Eberwein (1988) koncepciója pedig egy új, ,integrációs pedagógiáról” szólt, amely a reformpedagógiák tapasztalatait felhasználva, a gyógypedagógia és a pedagógia szintézisét vetette fel. Az integráció pedagógiájának már kifejezetten a neveléstudománnyal kapcsolatos elvárásait foglalja össze Feuser $(1989,2000)$ általános (gyermekközpontú) pedagógiája, amely az inklúzió felé mutat és a neveléstudomány minden gyermekre történő kiterjesztésére épít.

A gyógypedagógia elméletének a neveléstudományba történő beépítése és e két terület szintézisének felvetését követően azonban inkább ezen tudományterületek folyamatos párbeszédére és kooperációjára való igény jelent meg megoldásként. Speck (1998) gyógypedagógiáját zárt alrendszerként írta le, ugyanúgy mint az iskolai pedagógiát, a korai és óvodapedagógiát, a szakmai és felnőttképzést, valamint a szociálpedagógiát. Ezek a mezoszisztémák gyakran kerülnek kapcsolatba más alrendszerekkel, így egyszerre hangsúlyozza a különbözö pedagógiai alrendszerek különbségeit és egységét is. A neveléstudományt és a gyógypedagógiát az integrált nevelés elterjedésének hatására tehát nem egyesíti, sokkal inkább egy közös cél érdekében a különböző szakmai csoportokkal és „,pedagógiai alrendszerekkel” való együttmüködésre készteti. Döntően a kilencvenes években kidolgozott integrációs pedagógia hívei elsősorban gyógypedagógiai elméletalkotóként irányították a figyelmet arra az igényre, hogy az integráció hassa át a neveléstudományt is.

Az inkluzív nevelés új szemlélete megelevenítette nemcsak a gyógypedagógia, de a neveléstudomány világát is, s közben mindkét területen újraértelmezték viszonyrendszereiket. Az egyik oldalról az inkluzív nevelés külön elméleti rendszerként inkluzív pedagógiaként (Schnell és Sander, 2004; Réthy, 2004; Geiling és Hinz, 2005, Grubich et al., 2005), vagy a gyógypedagógia kibövitéseként (Biewer, 2009) jelent meg. Egyre erőteljesebben keresi a neveléstudomány is a társadalmi inklúzió elméletének hatásait az iskola mint társadalmi alrendszer vonatkozásában. Míg az inkluzív nevelés közös fogalmát vizsgálja, célkitüzését pontosítja, közben 
külön kezeli annak pedagógiai (Némethné, 2009; Schaffhauser, 2011) és gyógypedagógiai (Speck, 2010) hatásait, aspektusait.

A magyar gyógypedagógia önmagát „,pedagógiai dominanciájú komplex embertudományként” határozza meg, egyes ágai, a „nevelhetőség nehezített feltételeihez alkalmazkodó nevelési és terápiás folyamatok természetével foglalkoznak" (Mesterházi, 1998a, 11-13. o.), ugyanakkor a gyógypedagógiai tevékenységek közé tartozik a megelózés a pedagógiai kísérés, az életvezetés támogatása, a foglalkoztatás világában való aktív közremüködés (életsegítés) az egészségügyi intézményekben, valamint a szociális területeken végzett egyéb gyógypedagógiai tevékenység is. Mivel a gyógypedagógia kompetenciájának csupán egy része a nevelés, az inkluzív nevelés ehhez a tevékenységhez kapcsolódik elsősorban.

A folyamatosan megújuló gyógypedagógiai tevékenység az integratív nevelési megközelítés szerint kezdetben - mai szóhasználattal élve - a sajátos nevelési igényü tanulók számára nyújtott olyan gondoskodást, olyan nevelést, amelyet ez a kör addig nem igazán kapott meg. A magyar helyzet sajátságos abból a szempontból, hogy az integrált nevelés gondolata - eltérően a nyugat-európai, amerikai gyakorlattól - nem a szülők vagy civil testületek kezdeményezésére, nem polgárjogi mozgalmakhoz csatlakozva fogalmazódott meg, hanem a gyógypedagógiai ellátás állapotára reagáló, nemzetközi tapasztalatokkal rendelkezö, azokat Magyarországon is ismertető, gyógypedagógiát kutató oktatók indították el (Csányi, 1990; Lányiné, 1992). A folyamat következő állomásaként értelmezett inkluzív nevelés pedig egy iskolai átalakulási reformként értelmezhető (Papp, 2004), amely egyes iskolákban már elindult, de széles körüvé tétele még megvalósításra váró jövőkép csupán.

Nehezíti a tisztánlátást az inkluzív nevelés azon sajátossága, hogy egy fejlődő szakpolitikai (szociál- és oktatáspolitikai) koncepcióból indul ki, amelynek relatív és változó fogalmai, valamint a szakpolitikai jellege folyamatos kritika tárgyát képezik a tudomány világában. A szakmai viták hevében az inkluzív nevelést kritikusai a pedagógiai mítoszok körébe sorolják (Kobi, 2006), vagy fantazmagóriaként, utópiaként, patyomkin-faluként, homlokzatépítésként írják le (Speck, 2010), vagy romantikus fundamentalizmus, álmodozás, illúzió (Wocken, 2010) kifejezésekkel jellemzik. E kritikák kereszttüzében elsősorban az inklúzióval kapcsolatban megfogalmazott túlzottan idealisztikus, már-már paradicsomi célképzetek állnak. Az inkluzív nevelést támogató kutatók és szervezetek ezért maguk is szükségesnek látják ezen paradicsomi célképzetek relativizálását. Az inkluzív nevelés definíciója ennek megfelelően az inklúziót nem csupán célként, de a cél felé vezető útként, folyamatként jelenítik meg (Hinz, 2004; Booth, 2003; UNESCO, 2005).

Az exklúziótól az inklúzióig, a kirekesztéstől, a befogadásig vezető folyamat egyes stádiumai a nemzetközi tapasztalatok szerint országonként különbözőek is lehetnek attól függően, hogy miként befolyásolják az adott társadalom attitüdjei a hagyományosan kirekesztett csoportokkal kapcsolatos elkötelezettséget és cselekvéseket, a különféle szolgáltatások szintjét. Tipikusan azonban négy lépcsőfokra 
bontható az oktatási rendszereknek az inkluzív nevelés megvalósítása felé irányuló fejlődési folyamata. Az első lépcsőfokon a tagadó attitüdök jelennek meg, amelyek egyértelmü kirekesztést vonnak maguk után. A következő lépcsőfokon a jótékonyság és a karitativitás dominál, amely azonban szegregációhoz vezet. A harmadik lépcső már a megértésről szól, amely az integrációt, a speciális szükségletúek többségi intézményekben való nevelésének szemléletét, illetve gyakorlatát vonja maga után. A legfelső szint a tudatosságra épít, amely az inklúzió elterjedéséhez vezet a közoktatásban. Az attitüdváltás így különös jelentőségre tesz szert az iskolai folyamatokon belül is (UNESCO, 2005).

Ez az attitüdváltás szükséges a hazai iskolákban és a pedagógusképzés minden területén. A gyógypedagógiában bekövetkező változások nélkül nem kezdődhetett meg a fenti folyamat. Ugyanakkor a társadalom, az oktatáspolitika, a neveléstudomány különböző irányzatai, különösen az egyéni szükségletekre figyelő irányzatok, mozgalmak, illetve az esélyegyenlőségre, a méltányos oktatás megvalósítására törekvő megközelítések is nyitottak voltak a fogyatékossággal élő gyermekek sajátos szükségleteire, illetve befogadásukat ösztönző elméletekre, gyakorlatokra.

A továbbiakban a szerzők által fontosnak tartott események és trendek bemutatására kerül sor alapvetően az ELTE-hez kapcsolódóan.

\section{A gyógypedagógus-képzés átalakítása}

Az integráció témakörének oktatása elsőként a gyógypedagógus-képzésben jelent meg. Az integrációban megjelenő új gyógypedagógus-szerepnek megfelelően a rendszerváltás után a gyógypedagógus-képzés ún. „reform tantervének” keretein belül, 1992-től már jelentős hangsúlyt kapott. Különösen a gyógypedagógiai terapeuta feladatokra való felkészítés és az integráció nemzetközi eredményeinek közvetítése kapott hangsúlyt egy kötelező bevezető előadássorozatban, majd az integráció fogyatékosság-specifikus sajátosságainak kötelező szemináriumi keretekben és esetenként integrációs terepen végzett tanítási gyakorlatok formájában. Az intézményi tanterv-átalakítások folyamatosan reagáltak az újabb kihívásokra, ennek következtében az együttnevelésből fakadó újabb tantárgyi tartalmak és képzési módszerek a mai napig bővítik a képzést a hatékony integrált és inkluzív neveléshez szükséges többletkompetenciák kialakításának igényével és lehetőségeivel. A gyógypedagógus hallgatók felkészülnek a közoktatás palettáján megjelent, az együttnevelést segítő szak- és szakmai szolgáltatások ellátására, az EGYMI²-ben betöltött utazó gyógypedagógusi szerepre, a kéttanáros modell elméletére és gyakorlatára, az iskolában és annak környezetében megjelenő szakemberekkel, szülőkkel, történő együttmüködésre (Mesterházi, 2001; Papp, 2003, 2009).

\footnotetext{
${ }^{2}$ Egységes Gyógypedagógiai Módszertani Intézmény
} 
A gyógypedagógus képzés fejlesztése számára szakmai hátteret jelentettek az inkluzív nevelés nemzetközi szaktekintélyei, Mel Ainscow, majd Judy Sebba hazai szemináriumai 1995-ben és 1996-ban. Az UNESCO Ainscow által kidolgozott képzési csomagja 1996-ban megjelent magyarul, bázist teremtve a hazai inklúziós orientáltságú pedagógusképzési programok számára is.

A kilencvenes évek második felében a nemzetközi inklúziós célú képzésfejlesztések a virágkorukat élték. Ezek közül elsősorban a gyógypedagógus-képzés számára nyújtott nemzetközi tapasztalatszerzési és együttmüködési lehetőséget az „Inclusive Education" program, amelyben három együttmüködő partner ${ }^{3}$ felsőoktatási tantervfejlesztő innováció keretében jelenítette meg az inkluzív nevelést a gyógypedagógia mesterképzésén belül. A német és finn partnerekkel közösen kidolgozott képzés egyes elemei a gyógypedagógia szak mesterszintjén a „Fogyatékos emberek társadalmi integrációja" szakirányba épültek be. (Mesterházi, 2003). Emellett a közép-európai fejlesztések eredményeit is kamatoztatta a hazai gyógypedagógus-képzés (Zászkaliczky et al., 1999).

A nemzetközi együttmüködési projektek több oldalról is megerősítették a korábban inkább gyógypedagógiai kezdeményezéseket: mégpedig a tanító-, illetve a tanárképzés irányából.

\section{Változások a tanítóképzésben}

A gyógypedagógus-képzés és a tanítóképzés elkülönült rendszerében az integrált nevelés első hazai tapasztalatainak hatására e képzések közeledni kezdtek egymáshoz. Megkezdődött egyes tanítóképzőkben a gyógypedagógiai ismeretek oktatása, illetve Debrecenben és Kaposváron a tanítóképzés szakkollégiumi formában kívánt hozzájárulni ahhoz, hogy a tanítók felkészültek legyenek arra, hogy a tanulási nehézségekkel küzdö gyerekeket megtartsák a többségi iskoláztatás keretein belül (Mesterházi, 1988, 1989, 1998b, 2001). Érdekes módon e korai kezdeményezések oda vezettek, hogy egyre több tanítóképző nyitott tanulásban akadályozottak pedagógiája szakos gyógypedagógus-képzést, tehát a specializált ismeretek nemcsak az integrációra történő felkészítést erősítették a tanítóképzésen belül, inkább a gyógypedagógus-képzés elterjesztéséhez járultak hozzá néhány vidéki tanítóképző föiskolán.

A budai tanítóképzőben az integrált nevelés alapismeretei hosszú távon beépültek a tantervbe a „Differenciális pedagógia” címü alkalmazott pedagógiai stúdium keretein belül 1994-től. Emellett a képzőhely olyan, a pedagógia és a gyógypedagógia határterületeit érintő témaköröket is megjelenített továbbképzéseiben, mint a tanulási és a magatartási zavar (Kereszty, 1999a; Glauber és Tihanyiné, 2006). Ehhez egy nemzetközi együttmúködés keretében jelentős támogatásokat nyújtott a Bu-

\footnotetext{
${ }^{3}$ A partnerek: Evangelische Fachhochschule Darmstadt, ELTE Bárczi Gusztáv Gyógypedagógiai Kar, University Kuopio
} 
dai Tanítóképző Főiskola és a Bárczi Gusztáv Gyógypedagógiai Tanárképző Főiskola $^{5}$ közös TEMPUS projektje, amely a két képzés egymáshoz történő közelítése érdekében kezdte meg együttmüködését. A projekt a nemzetközi tapasztalatszerzés mellett a hazai integrációs iskolai mühelyek megerösítésével és a befogadó iskola koncepciójának megjelenítésével lépett előre az integrációs törekvések felől az inklúziós törekvések irányába. A gyógypedagógus-képzéssel együttmüködve születtek meg a kilencvenes években azok a tantárgyak a tanítók és óvodapedagógusok képzésében, amelyek felkészítenek a differenciált oktatásra, így azóta is segítik az integráció megvalósítását a többségi intézményekben (Gereben és Kereszty, 1996) sőt már nemcsak az integrált nevelés, de az inkluzív iskola koncepcióját is közvetítik (Kereszty, 1999b).

\section{Változások a tanárképzésben}

A tanárképzést hazánkban elsőként az INTEGER nemzetközi pedagógus-továbbképzési projekt vonta be az integrációs törekvésekbe, amely az Európa Unió SOCRATES projektjének keretei között szerveződött 1997-töl osztrák, olasz, spanyol, német, dán, ír és skót kollégák együttmüködésében (Feyerer, 2000). A programhoz 1998ban csatlakozott az ELTE BTK Neveléstudományi Intézete 6 . A projekt eredményeként az ELTE tanárképzésébe 1999-től beépült a „Különleges bánásmódot igénylő gyermekek inkluzív nevelése" címü szeminárium. Ezzel párhuzamosan megjelentek az integrációhoz kapcsolódó elméletek a tanárképzés egyes tantárgyaiban, témaköreiben (Petriné, 1998).

Az INTEGER program folytatásaként az $\mathrm{EUMIE}^{7}$ projekt 2001-2004-ig müködött osztrák, német, skót, norvég, spanyol és magyar egyetemek kutatócsoportjainak közremüködésével. A projekt eredménye az EUMIE mesterstúdium lett. Az EUMIE egy moduláris tanterv, moduljai meghirdetésre kerülhetnek önálló kurzusként és egy átfogó képzési program részeként egyaránt (Feyerer, 2004; Feyerer és Schaffhauser, 2005; Schiffer, 2005; Réthy, Schaffhauser és Schiffer, 2006). Így elöször a pedagógia szakos hallgatók specializációjaként, később tanártovábbképzésként, végül pedig egyetemi mellékszakként akkreditálására került az EUMIE alapján készült, majd pedig az ELTE PPK és BGGYFK együttműködésével a hazai felsőoktatási helyzetre átalakított 40 kredites tanári mellékszak inkluzív nevelőtanár néven, amely az utóbbi években több felsőoktatási intézmény kínálatában is megjelent.

\footnotetext{
${ }^{4}$ 2000-től ELTE Tanító- és Óvóképző Főiskolai Kar, majd 2009-től ELTE Tanító- és Óvóképző Kar ${ }^{5}$ 2000-től ELTE Bárczi Gusztáv Gyógypedagógiai Főiskolai Kar, majd 2009-től ELTE Bárczi Gusztáv Gyógypedagógiai Kar

${ }^{6}$ 2003-tól ELTE Pedagógiai és Pszichológiai Kar Neveléstudományi Intézet

${ }^{7}$ European Masters in Inclusive Education
} 
Szintén az Európai Unió Socrates programjának támogatásával készült el a „,European Perspectives on Social Inclusion" címen egy társadalmi inklúziós tanácsadó mesterképzés 2000-2003 között angol, német, svéd, portugál, román és magyar egyetemek kutatóinak közreműködésével, amelynek hazai résztvevői az ELTE Pszichológiai Intézet kutatói voltak. A 120 kredites program oktatását a képzést kidolgozó hét ország szakemberei vállalták, amelyhez elkészültek a főként angol nyelvü, de részben a kidolgozók nyelvén is rendelkezésre álló tanulmányok tanulmánykötetei, amelyek a képzés teljes tartalmát magukba foglalják (Eriksson et al., 2003; Johnstone, 2003, Stoer et al., 2003; Bloemers et al., 2004). A képzés „,társadalmi integrációs tanácsadó" néven szakirányú továbbképzésként került akkreditálásra, azonban eddig még nem indult.

Szintén a pedagógusképzés inkluzív orientációjú megújításának céljából készült dán-magyar együttmüködésben az „Inklúziós tanterv és útmutató a magyarországi pedagógusképzés számára" címü képzési anyag, amelynek során egyetemi és föiskolai oktatókat képeztek ki tanfolyamokon, valamint hazai és külföldi (dániai) intézménylátogatások alkalmával az inklúzió oktatására (Csányi et al., 2009). Ennek eredményeképpen több egyetem és föiskola kínálatában néhány féléven keresztül jelen volt egy-egy további, a „mindenki iskolájában” való tanításra felkészítő kurzus, és a mindenki iskolájának eszméje megjelent később az ELTE tanárképzésének bolognai rendszerü továbbfejlesztésében is.

A fenti kezdeményezések fokozatosan hozzájárultak ahhoz, hogy teret nyerjen az inkluzív nevelés szemlélete, és egyes elemeinek oktatása meg is kezdődjön a tanárképzésben. A tanárképzés rendszerváltás utáni átalakításáról szóló kormányrendelet 1997-ben ${ }^{8}$ sem az integrált, sem az inkluzív nevelésről szóló tudástartalmakat közvetlenül nem írt elö a tanárjelöltek számára, mégis közelített ennek oktatása felé azzal, hogy megjelenítette a differenciálás, a nehezen nevelhető gyermekek oktatása, a gyógypedagógiai problémák felismerése, a gyermek- és ifjúságvédelem, a tehetséggondozás és a felzárkóztatás témaköreit a tanárképzésben.

Az ELTE tanárképzésében 2002-től a „Hátrányos helyzetű fiatalok nevelése” tantárgyblokk közvetítette a kormányrendelet által elóírt fenti tartalmakat. A tantárgyblokkon belül kötelezően választható módon jelent meg a roma, a szociálisan hátrányos helyzetü, a tanulási zavarral küzdő tanulók nevelése, a multikulturális nevelés és már közvetlenül az inkluzív nevelés is. Ezen tanegységek közül a tanárjelölteknek egyet kellett választaniuk.

A Bolognai Nyilatkozat (1999) nyomán kialakult felsőoktatási reform 2006ban új pedagógusképzési struktúrát és tantervet vont maga után. A korábbi tantervhez hasonlóan ebben is választható tantárgyblokk keretein belül jelentek meg az integrált és inkluzív neveléssel kapcsolatos tantárgyak. Az új, Mindenki iskolája tantárgyblokkban azonban nem csupán átnevezték a régi tantárgyakat, de tartalmi,

\footnotetext{
${ }^{8}$ 111/1997. (VI. 27.) Korm. rendelet a tanári képesítés követelményeiről
} 
szemléletbeli változások is történtek. A tantárgyblokk Golnhofer Erzsébet által vezetett átalakításának sajátossága, hogy miután szembesültek az integráció és az inklúzió kihívásaival (a tág értelemben: a szociálisan hátrányos helyzetủ, a roma és a kisebbségi tanulókat is beleértve), ezeknek megfelelően oldották meg a szemléleti és tartalmi változtatásokat. A Mindenki iskolája tantárgyblokk az ELTE tantervében számos választható tanegységet foglal magában, amelyek mindegyikében mintegy 30\%-os közös tartalom megtalálható. ${ }^{9}$

Az integráció, inklúzió szemléletének elterjedése szempontjából előremutató továbbá, hogy az elmúlt években a Neveléstudományi Intézet oktatói közül többen részt vettek az integrációhoz, illetve az SNI tanulók támogatáshoz kacsolódó programokban, mint például a nemzetközi érdeklődést is kiváltó Dobbantó program$\operatorname{ban}^{10}$. Az Alkalmazott Neveléselméleti Tanszék munkatársainak módszertani mühelymunkája eredményeképpen pedig megszületett a Módszertár felsőfokon c. kötet (Trencsényi, 2009), amely a pedagógusképzés oktatóit támogatja módszertani javaslatokkal a neveléselmélet és az együttnevelés közvetítésében. 2010-től folytatódott ez a fejlesztés immár egy Mindenki iskolája címü, feladat- és módszertani gyüjtemény elkészítésének formájában.

\section{Inkluzív pedagógusképzés}

Az inkluzív pedagógusképzés ${ }^{11}$ igénye azt követően vetődött fel, hogy a nemzetközi szervezeteken, elsősorban az UNESCO-n túl az Európai Unió szociál- és oktatáspolitikája is zászlajára tüzte az inkluzív közoktatás megvalósítását. Az inkluzív pedagógusképzés elsősorban inkluzív szemléletủ pedagógusok képzését jelenti, akik képesek a befogadó iskolákban ellátni a pedagógusi feladatokat és felelősséget vállalni minden diák tanulásáert. Ez nem a pedagógusképzés egy újabb specializált formája, hanem minden pedagógus képzésével kapcsolatos európai elvárás.

Már a kilencvenes évektől az inkluzív iskolákban történő pedagógiai munkával kapcsolatban - az UNESCO ajánlásaira hivatkozva - megjelent az az igény, hogy egy befogadó intézmény „nemcsak egyszerüen eltüri, hogy oda egy-egy speciális nevelési szükségletü gyermek jár, hanem tesz is érte: egyénileg differenciált, változatos módszereket, rugalmas tantervi követelményeket alkalmaznak a pedagógusok, szemléletváltozás zajlik a tantestületben, melynek tagjai feladatuknak érzik a kör-

\footnotetext{
${ }^{9}$ Adaptív nevelés, Inkluzív nevelés, Inter- és multikulturális nevelés, Intézményes segítségnyújtás, támogatás, Szabadidő-pedagógia, Szociális kompetenciák fejlesztése, Szociális munka az iskolában, Tanulási és magatartási zavar, Tehetséggondozás, Változó család - változó iskola (ELTE tanterv, 2006)

${ }^{10} \mathrm{http} / / / \mathrm{fszk} \cdot \mathrm{hu} /$ index.php?option=com_content\&view=category\&id=68\&Itemid=117

${ }^{11}$ Bár a nemzetközi szakpolitikák és kutatások fordításaként a hazai szakirodalmakban is gyakori a tanárképzés mint főfogalom használata, a magyar nyelvben elkülönülő tanító, tanár, gyógypedagógus stb. képzések együttes megnevezésére a pedagógusképzést ajánljuk.
} 
zet valamennyi gyermekének, így a speciális nevelési szükségletủ tanulóknak az ellátását is" (Csányi et al., 1994, 9-10. o.). Mindez a pedagógusok továbbképzésének szükségessége mellett áttételesen az alapképzés számára is iránymutatást jelenthetett: a pedagógusképzésben már meglévő, egyéni sajátosságokra figyelő tartalmak (differenciált oktatás, kooperatív és projektoktatás) súlyát erősítették az inklúzió szemléletével és annak jogi és szervezeti alapjainak megjelenésével.

A hazai pedagógusképzési tapasztalatokat is felhasználó inklúziós pedagógusképző programcsomagok 2005 és 2008 között készülhettek el az Európai Unió támogatásával az NFT ${ }^{12}$ HEFOP $^{13}$-jainak keretén belül az SNI és a roma tanulók befogadására történő felkészítés érdekében. A programcsomagok a felsőoktatási alapképzésben a nappali tagozatos óvodapedagógus, tanító- és tanárképzést célozták meg. Az SNI programcsomagok a korábbinál szélesebb körben próbálták beépíteni ezen képzésekbe az inkluzív neveléssel kapcsolatos szemléletformáló, valamint a diagnosztikai és terápiás lehetőségekről tájékoztató tanegységeket (Auer et al., 2007; Csányi et al., 2007; Áment et al., 2008). Az elkészült képzési anyagokat tíz felsőoktatási intézményben 20 oktató próbálta ki, és bár az eredeti céltól eltérően a program nem jelent meg az összes pedagógusképző intézmény kínálatában, de számos oktató inkluzív nevelés iránti elkötelezettségét növelte (Torda és Perlusz, $2009^{14}$ ).

Mindezek kiegészítéseként további programcsomagok is készültek az SNI inklúziós felsőoktatási képzések, valamint pedagógus és más szakembereknek szóló továbbképzések céljára (Szabó, 2006; 2007; Vargáné, 2006). Az ezzel párhuzamosan kidolgozott roma integrációs felsőoktatási programcsomagok hasonló struktúrában és témakörökben foglalkoztak a differenciálással, a kooperatív tanulással, a tevékenységközpontú pedagógiákkal, a projektoktatással, a multikulturális és interkulturális neveléssel, a tanulók megismerésével, a patronáló rendszerekkel, az integrált oktatás jogi, társadalmi és pedagógiai hátterével, azok roma integrációs vonatkozásait kidolgozva. Ezek eredménye összesen 11 képzési anyag és 19 gyakorlati kézikönyv és integrációs pedagógia mühely füzet lett. A felsőoktatási fejlesztések nagy lendülettel indultak, de a továbbiakban az inklúzió szemléletének megfelelően - amelyben minden gyermek együtt tanításáról van szó - ezen oktatási programcsomagok szemléleti és tartalmi összehangolására is szükség lenne.

Kifejezetten a pedagógusképzések számára kidolgozott csomagok mellett a társadalmi inklúzió, vagyis a közoktatás világán túli befogadás, együttélés fejlesztése céljával a Fogyatékos Személyek Esélyegyenlőségéért Közalapítvány is kidolgoztatott felsőoktatási programcsomagokat a fogyatékosságügyet érintő felsőoktatási képzések és továbbképzések számára, amelyek között a pedagógusképzésben is alkalmazható szemléletformáló tréningek és szemináriumok is szerepelnek. Ezek pró-

\footnotetext{
${ }^{12}$ Nemzeti Fejlesztési Terv

${ }^{13}$ Humánerőforrás-fejlesztési Operatív Program

${ }^{14}$ A programról a Pedagógusképzés e számában lásd Marton Eszter-Papp Gabriella-Perlusz Andrea: Másképp - Az egyéni szükségletekhez, igényekhez igazitott pedagógus-továbbképzés a gyakorlatban.
} 
baképzései a 2009-2010-es tanévben történtek, a képzők képzése a 2010-2011-es tanévben zajlott és a közeljövőben várható a képzési programok disszeminációja ${ }^{15}$.

A hazai pedagógusképzésben és -továbbképzésben szerkezetileg és tartalmilag is beépült az inkluzív iskolákban megjelenő feladatokra történő felkészítés az elmúlt években. Az inkluzív pedagógusképzés megteremtésének újonnan megfogalmazott szakmapolitikai igénye folyamatosan ösztönzi az egyes országok oktatási rendszereit a továbbfejlődésre ezen a téren. Az oktatáspolitikai célok megvalósítása érdekében az EADSNE ${ }^{16}$ a közelmúltban gyüjtötte össze a befogadást elősegítő pedagógusképzéssel összefüggő politikával és gyakorlattal kapcsolatos nemzetközi tapasztalatokat 29 európai ország gyakorlatából. Arra a kérdésre kereste a választ, „hogyan készíthetök fel a tanárok alapképzésük során arra, hogy 'befogadókká' váljanak?" (EADSNE, 2011).

A nemzetközi tapasztalatok alapján az inkluzív pedagógusképzés három fó megközelítési módja körvonalazódik. A külön kurzusok elkülönült tanegységekben közvetítik a tudástartalmakat, az integrált kurzusokat az általános és a speciális neveléssel, oktatással foglalkozó fakultások és a gyakorló intézmények tanári kara közötti együttmüködés révén fejlesztik ki és építik be a pedagógusképzésbe, valamint az egyesitett kurzusok, amelyekben a minden pedagógusjelöltre kiterjedö alapképzés inklúzió által áthatott egésze vértezi fel öket azokkal a készségekkel, tudással és hozzáállással, amelyek segítségével felelösséget vállalhatnak és megfelelhetnek valamennyi tanuló igényeinek és szükségleteinek" (Pugach és Blanton, idézi $E A D S N E$, 2011, 27. o.).

Mindegyik képzési formára számos példa akad nemzetközi és hazai szinten is. A hazai inklúziós pedagógusképzési programok kezdetben föként külön, önálló, a képzésben szigetként megjelenő, csupán azt „,színesítő” előadások, szemináriumok formájában voltak jelen a föiskolák, egyetemek kínálatában, és ez a forma még ma is gyakori. Továbblépést jelent, ha megjelennek a képzés szerves részét képező, abba tartósan beépülő, integrált kurzusok, amelyek azonban a hazai felsőoktatásban szinte kizárólag a kötelezően választható tantárgyak körében találhatóak, így csak a pedagógusjelöltek egy részéhez jutnak el, és e tárgyak gyakran az inkluzív nevelés egy-egy szükebb területét tárgyalják csupán.

Az egyesített vagy összevont kurzusok már a képzés szerves részét alkotják, olyan pedagógusképzését, amelyet áthat az inklúzió szemlélete. Az inklúziós tudáselemek szinte minden tanegységben jelen vannak, de akár modulként is összefoghatnak olyan tantárgycsoportokat, amelyek több oldalról közelítenek az inklúzió felé, bár érdemes megjegyezni, hogy nagy szükség van e tárgyak összehangolására. Ebbe az irányba indult el az ELTE pedagógusképzése és ilyen irányú változásokra kész-

\footnotetext{
${ }^{15}$ http://www.fszk.hu/index.php?option=com_content\&view=article\&id=191:kepzk-kepzese-felsoktatasies-felnttkepzesi-intezmenyek-oktatoi-kepzi-reszere\&catid=98:palyazatok\&Itemid=131

${ }^{16}$ European Agency for Development in Special Needs Education
} 
tetik az elözőekben bemutatott pedagógusképzési programcsomagok a hazai pedagógusképző felsőoktatási intézményeket.

Az egyesített kurzusokat eredményesebbé tehetné, ha egy kurzuson belül együtt készítenék fel pedagógiai feladataikra a későbbiekben különböző végzettséget szerző pedagógusjelölteket. Ilyen szemináriumokat csupán néhány alkalommal sikerült indítani az ELTE-n, együtt oktatva gyógypedagógus- és tanárképzésének hallgatóit 2007-2009 között. Ezek a képzések azért eredményesek, mert a hallgatók egyrészt már az alapképzésben megélhetik saját különbözőségeiket, másrészt úgy építhetik ki egyéni szakmai identitásukat, hogy abban nemcsak a tanulók, de a későbbi kollégák közötti heterogenitás is értékként jelenik meg, továbbá gyakorlati tapasztalatok által sajátíthatják el a szakmai együttmüködés alapjait.

A nemzetközi tapasztalatok azt mutatják, hogy a hallgatók szemléletformálásában nagy jelentőségúek azok a tantárgyak, amelyek lehetőséget adnak a különbözőség megélésére, a különböző kultúrájú vagy fogyatékos emberekkel való közvetlen kapcsolatteremtésre heterogén hallgatói csoportok létrehozásával, valamint gyakorlati, konkrét példák, kapcsolatteremtési feladatok segítségével. A kurzusok reflektív gyakorlatokon keresztül lehetőséget teremtenek a tapasztalatok összegzésére, átadására, értékek felismerésére és saját kompetenciáik feltérképezésére, fejlesztésére is (EADSNE, 2011).

Az inkluzív pedagógusképzés azt is igényli, hogy a pedagógusjelöltek inkluzív nevelést folytató (gyakorló)iskolákban, osztályokban is tapasztalatokat gyüjtsenek, sőt gyakorló tanításaik egy részét ilyen közegben végezzék. Ezt ösztönzi a fenti nemzetközi ügynökség (EADSNE) mellett az ENSZ Fogyatékossággal élő személyek jogairól szóló Egyezménye is.

Figyelemre méltó, hogy nemzetközi diskurzus bontakozott ki arról, milyen kompetenciákra van szüksége egy inkluzív szemléletü pedagógusnak. Az ismeretek vonatkozásában a hazai törekvésekhez hasonlóan a különböző országok szakemberei a sajátos nevelési igényekkel, felismerésükkel, kielégítésükkel, a tanulási nehézségek megelőzésével, az egyéni differenciálással és a jogi szabályzókkal kapcsolatos tájékozottságot említették leginkább, és ezek mellett az értékelés, a szülőkkel, a kollégákkal és a segítő szakemberekkel való együttmüködés készségei is megjelentek, de a kíváncsiságot, a kritikus gondolkodást, a rugalmasságot, valamint a felelösségérzetet is megemlítették. Az országok többsége mindezek mellett olyan kulcskompetenciákat emelt ki, mint a saját tanulási folyamat rendszeres végiggondolása, az állandó információkeresés, a befogadó tanítási módszerek széles skálájának, a csoportos és az egyéni munkamódszereknek az alkalmazása, hatékonyságuk értékelése, továbbá a soknyelvü kontextusban szükséges nyelvtanulás és a kulturális sokféleség erőforrásként történő értékelése (EADSNE, 2011, 61-62. o.).

Mindezen kompetenciák egy része megjelent az ELTE részletes tanári kompetencialistájában is (2006), köztük az inklúzió szemléletének megértésére és elfogadására törekvés, az inklúzió jogi és oktatáspolitikai aspektusának hazai és európai 
dimenzióira vonatkozó ismeretek, együttmüködési készség, képesség a pedagógus kollégákkal, az iskola más munkatársaival, a szülőkkel és a tanulók életében szerepet játszó más szakemberekkel, intézményekkel, szervezetekkel és szolgáltatásokkal. Ezt a kezdeményezést előremutatónak tekintjük, hiszen megmutatja, hogy a hazai pedagógusképzés elindult az inkluzív pedagógusképzés megvalósításának irányába.

Az inkluzív pedagógusképzés célját abban határozzuk meg, hogy „valamennyi tanárnak már képzése kezdeti szakaszában fel kell készülnie arra, hogy a befogadó nevelés területén dolgozzon, majd lehetőséget kell kapnia további munkahelyi képzésre karrierje során, hogy fejleszteni tudja tudását és készségeit, befogadó környezetben tudja szélesíteni gyakorlati befogadó ismereteit" (EADSNE, 2009, 19. o.). Bár a hazai kezdeményezések nagyon előremutatóak, e cél elérése nemzetközi öszszehasonlításban még meglehetősen távolinak tünik.

\section{Irodalom}

Ainscow, M. (1996): Speciális szükségletek az osztályban. Bárczi Gusztáv Gyógypedagógiai Tanárképző Főiskola, Budapest.

Áment Erzsébet, Fecskó Edina, Heimann Ilona, Kovács Andrea, Kulcsár Papp Enikő, Makai Éva, Poór Zoltán (2008): Inkluzív nevelés - „Mindenki másképp egyforma” az integrációban. Attitüdformáló pedagógusképzési program. Kézikönyv a pedagógusképző intézmények részére. Educatio, Budapest.

Andorka Rudolf (1997): Bevezetés a szociológiába. Osiris kiadó, Budapest.

Auer Éva, Fótiné Hoffmann Éva, Mohr Marianna, Radványi Katalin, Sándor Éva, Schiffer Csilla, T. Kovács László (2007): Inkluziv nevelés. Habilitációs és rehabilitációs tevékenységek. Kézikönyv a pedagógusképző intézmények részére. SuliNova, Budapest.

Biewer, G. (2009): Grundlagen der Heilpädagogik und Inklusiven Pädagogik. Klinkhardt, Bad Heilbrunn.

Bloemers, W., Johnstone, D., Rodrigues, D., Wisch, F. H. (2004): European Perspectives on Disabled People. Peter Lang, Frankfurt am Main, Berlin, Bern, Bruxelles, New York, Oxford, Wien.

Booth, T. (2003): Viewing inclusion from a distance: gaining perspective from comparative study. In: Nind, M. - Rix, J. - Sheehy, K. - Simmons, K. (eds): Inclusive Education: Diverse Perspectives. Fulton, London, 253-263.

Csányi Yvonne (1990): Fogyatékosok integrációja - nemzetközi és hazai áttekintés. Gyógypedagógiai Szemle, 4. sz. 271-280.

Csányi Yvonne (1991): Integráció - a „normál” pedagógia és a gyógypedagógia új együttmüködési formája. Új Pedagógiai Szemle, 12. sz. 38-44.

Csányi Yvonne (2000): A speciális nevelési szükségletủ gyermekek és fiatalok integrált nevelése-oktatása. In: Illyés Sándor (szerk.): Gyógypedagógiai alapismeretek. ELTE BGGYFK, Budapest, 377-408. 
Csányi Yvonne, Deák Tiborné, Gyöngyösi Lászlóné (1994): A hallássérült tanulók integrált oktatásáról. Tájékoztató és útmutató. Bárczi Gusztáv Gyógypedagógiai Tanárképző Főiskola, Szurdopedagógiai Tanszék, Budapest.

Csányi Yvonne, Egyed Katalin, Fazekasné Fenyvesi Margit, Gál Sándorné, Girasek János, Glauber Anna, Kovátsné Németh Mária, Szegál Borisz, Tóth László (2007): Inkluziv nevelés - A tanulók hatékony megismerése. Kézikönyv pedagógusképző intézmények részére. SuliNova, Budapest.

Csányi Yvonne, Fótiné Hoffmann Éva, Kereszty Zsuzsa, Nagyné Kováts Ildikó, Willumsen, John (2009): Inklíziós tanterv és útmutató a magyarországi pedagógusképzés számára. Oktatási segédanyag. GYISM, Budapest.

Dreher, W. (1996): Denkspuren: Bildung von Menschen mit geistiger Behinderung Basis einer integralen Pädagogik. Mainz, Aachen.

EADSNE (2009): A minöség fejlesztésének alapelvei a befogadó nevelésben - Ajánlások az oktatáspolitika számára. Európai Ügynökség a Sajátos Nevelési Igényü Tanulók Oktatásának Fejlesztéséért, Odense.

EADSNE (2011): Pedagógusképzés a befogadó oktatásért Európában - Kihivások és lehetőségek. Európai Ügynökség a Sajátos Nevelési Igényü Tanulók Oktatásának Fejlesztéséért, Odense.

Eberwein, H. (1988): Behinderte und Nichtbehinderte lernen gemeinsam. Handbuch der Integrationspädagogik. Beltz, Weinheim, Basel.

ELTE PPK (2006): A tanárképzés képesitési követelményei. Munkaanyag.

Eriksson, B., Falch, A. B., Lisznyai Sándor, Ritoók Magda (2003): Theories of Intervention and Social Change. Peter Lang, Frankfurt am Main, Berlin, Bern, Bruxelles, New York, Oxford, Wien.

Feuser, G. (1989): Allgemeine integrative Pädagogik und entwicklungslogische Didaktik. Behindertenpädagogik, No. 1.4-48.

Feuser, G. (2000): Zum Verhältnis von Sonder- und Integrationspädagogik - eine Paradigmendiskussion? Zur Inflation eines Begriffes, der bislang ein Wort geblieben ist. In: Albrecht, F. - Hinz, A. - Moser, Vera (Hrsg.): Perspektiven der Sonderpädagogik. Disziplin und professionsbezogene Standortbestimmung. Luchterhand, Neuwied, 20-44.

Feyerer, E. (2000): INTEGER - Ein europäisches Curriculumentwicklungs-programm für eine integrative Lehrerausbildung. In: Feyerer, E. - Prammer, W. (szerk.): 10 Jahre Integration in Oberösterreich. Ein Grund zum Feiern!? Trauner, Linz, 198-204.

Feyerer, E. (2004, szerk.): EUMIE European Masters in Inclusive Education. Ein Curriculumentwicklungsprogramm im Rahmen von SOCRATES ERASMUS. Linz.

Feyerer, E., Schaffhauser F. (szerk., 2005): Az ,inkluzív nevelés” mesterfokú képzés európai tanterve. Magánkiadás, Budapest.

Geiling, U., Hinz, A. (szerk., 2005): Integrationspädagogik im Diskurs. Auf dem Weg zu einer inklusiven Pädagogik? Klinkhardt, Bad Heilbrunn.

Gereben Ferencné, Kereszty Zsuzsa (1996): Különböznek. Differenciálás kisiskolás korban. Budapesti Tanítóképzö Főiskola, Neveléstudományi Tanszék, Budapest. 
Glauber Anna, Tihanyiné Hős Ágnes (2006): Befogadó szemlélet kialakítása az óvó- és tanítóképzésben. Pedagógusképzés, 1-2. sz. 77-86.

Grubich, R. et al. (2005): Inklusive Pädagogik. Beiträge zu einem anderen Verständniss von Integration. Innsalz, Wien.

Havas Gábor, Kemény István, Liskó Ilona (2002): Cigány gyerekek az általános iskolában. Új Mandátum Könyvkiadó, Budapest.

Hinz, A. (2002): Von der Integration zur Inklusion - terminologisches Spiel oder konzeptionelle Weiterentwicklung? Zeitschrift für Heilpädagogik, No. 9. 354-361.

Hinz, A. (2004): Vom sonderpädagogischen Verständnis der Integration zum integrationspädagogischen Verständnis der Inklusion!? In: Schnell, I., Sander, A. (Hrsg.): Inklusive Pädagogik. Klinkhardt, Bad Heilbrunn, 41-74.

Illyés Sándor (2001): Az eszmény, a törvény, a tradíció és a feltételek a közoktatás megújulásában - különös tekintettel az ép és a fogyatékos gyermekek együttnevelésére. $U_{j}$ Pedagógiai Szemle, 7. sz. 3-7.

Johnstone, D. (2003): Comparative Social Policies in Europe. Peter Lang, Frankfurt am Main, Berlin, Bern, Bruxelles, New York, Oxford, Wien.

Kalocsainé Sántha Hajnalka, Varga Aranka (2005): Az inklúzió mint társadalmi és oktatási idea. Educatio, 1. sz. 204-208.

Kereszty Zsuzsa (1999a): Befogadó szemlélet és gyakorlat a tanítóképzésben. In: Kereszty Zsuzsa (szerk.): Mindenki iskolája. Együttnevelés. IFA-BTF-OM, Budapest, 91-105.

Kereszty Zsuzsa (1999b, szerk.): Mindenki iskolája. Együttnevelés. Sajátos nevelési szükségletü gyermekek többségi iskolában. IFA-BTF-OM.

Kobi, E. E. (2006): Inklusion: ein pädagogischer Mythos? In: Dederich, M., Greving, H., Mürner, Chr. - Rödler, P. (Hrsg.): Inklusion statt Integration? Heilpädagogik als Kulturtechnik. Psychosozial-Verlag, Gießen, 28-44.

Lannert Judit (2004): A társadalmi kirekesztődés folyamata az oktatásban. In: Monostori Judit - Sághi Gábor - Merkl Ildikó (szerk.): A szegénység és a társadalmi kirekesztödés folyamata. KSH, Budapest.

Lányiné Engelmayer Ágnes (1987): Az integrációs nevelési kísérletek pszichológiai megközelítésben. Pedagógiai Szemle, 9. sz. 931-934.

Lányiné Engelmayer Ágnes (1992): A külföldi integrációs modellek tanulságai a hazai alkalmazás számára. Új Pedagógiai Szemle, 4. sz. 56-60.

Mesterházi Zsuzsa (1988): Tanítójelöltek felkészítése problémás gyerekek nevelésére. Szakkollégiumi képzési kísérlet. Tájékoztató a közoktatási kutatásokról. Tanulmányok. Közoktatási Kutatások Titkársága, Budapest, 45-64.

Mesterházi Zsuzsa (1989): Modell a kisegítő iskolai szakkollégiumra a tanítóképző főiskolákon. In: Fábián Zoltán (szerk.): Új modellek a tanitóképzésben. Tankönyvkiadó, Budapest, 134-145.

Mesterházi Zsuzsa (1998a): A gyógypedagógus kompetenciája és interdiszciplináris helyzete. Gyógypedagógiai Szemle, Különszám, 9-13.

Mesterházi Zsuzsa (1998b): A gyógypedagógus képzés és a tanítóképzés együttmüködésének tapasztalatai. In: Schablauerné Kertész Klára. (szerk.): A tanitók és óvodapedagó- 
gusok felkészitése a fogyatékos gyermekek fejlesztésére. Csokonai Vitéz Mihály Tanítóképző Főiskola, Kaposvár, 21-25.

Mesterházi Zsuzsa (2001): A különtámogatást igénylő gyermekek szükségleteinek kielégítésére felkészült pedagógusok képzésének dilemmái. Educatio, 2. sz. 255-266.

Mesterházi Zsuzsa (2003): A pedagógiai és társadalmi integrációt elősegitő szakemberek képzése nemzetközi együttműködéssel. Gyógypedagógiai Szemle, 3. sz. 183-186.

Némethné Tóth Ágnes (2009): Tanári attitüdök és inkluzív nevelés. Magyar Pedagógia, 2. sz. $105-120$.

Papp Gabriella (2003): Felkészítés speciális pedagógiai feladatokra. Pedagógusképzés a 21. században ELTE Modell 1. Az ELTE-n 2003. szeptember 11-én megtartott vitaülés anyaga. ELTE Eötvös Kiadó, Budapest, 54-58.

Papp Gabriella (2004): Tanulásban akadályozott gyermekek a többségi általános iskolában. Comenius, Pécs.

Papp Gabriella (2009): BA, MA, PHD-eredmények a gyógypedagógiai felsőoktatásban történeti megközelítésben. In: Karlovitz János Tibor (szerk.): Speciális kérdések és nézöpontok a felsőoktatásban. Neveléstudományi Egyesület Kiskönyvtára, 1. Neveléstudományi Egyesület, Budapest, 41-48.

Petriné Feyér Judit (1998): A különleges bánásmódot igénylő gyermek. In: Falus Iván (szerk.): Didaktika. Nemzeti Tankönyvkiadó, Budapest, 435-464.

Pijl, S. J., Meijer, C. J. W., Hegarty, S. (1997. szerk.): Inclusive education: a global agenda. Routledge, London.

Réthy Endréné (2004): Inkluzív pedagógia. In: Nahalka István és Torgyik Judit (szerk.): Megközelitések. Roma gyerekek nevelésének egyes kérdései. Eötvös József Könyvkiadó, Budapest, 231-245.

Réthy Endréné, Schaffhauser Franz, Schiffer Csilla (2006): Az EUMIE mesterfokú tanterv - inkluzív nevelés szakon. Pedagógusképzés, 1-2. sz. 93-99.

Rödler, P. (1993): Menschen, lebenslang auf Hilfe anderer angewiesen. Grundlagen einer allgemeinen basalen Pädagogik. AFRA Verlag, Frankfurt am Main.

Schaffhauser Franz (2011): Az iskola feladata a sajátos nevelési igényü tanulók integrálásában - az inklúzió pedagógiája. In: Bábosik István - Borosán Lívia - Hunyady Györgyné - M. Nádasi Mária - Schaffhauser Franz: Pedagógia az iskolában. ELTE Eötvös Kiadó, Budapest, 263-352.

Schiffer Csilla (2005): Inkluzív Nevelés MA képzés európai tanterve. Pedagógusképzés, 1. sz. $135-140$.

Schnell, I. - Sander, A. (szerk.): Inklusive Pädagogik. Klinkhardt, Bad Heilbrunn.

Simon Mária (2005): A bevándorló gyerekek iskolai integrációja Európában. Új Pedagógiai Szemle, 7-8. sz. 205-213.

Speck, O. (1998): System Heilpädagogik: Ein ökologisch reflexive Grundlegung. Reinhardt, München.

Speck, O. (2010): Schulischer Inklusion aus heilpädagogischer Sicht. Rhetorik und Realität. Reinhardt, München, Basel. 
Stoer, S. R., Rodrigues, D., Magalhaes, A. M. (2003): Theories of Social Exclusion. Peter Lang, Frankfurt am Main, Berlin, Bern, Bruxelles, New York, Oxford, Wien.

Szabó Ákosné (szerk., 2006): Inkluzív nevelés - Projektpedagógia. Kézikönyv a pedagógusképző intézmények számára. SuliNova, Budapest.

Szabó Ákosné (szerk., 2007): Inkluzív nevelés - Kooperatív tanulás. Kézikönyv a pedagógusképző intézmények számára. Educatio, Budapest.

Torda Ágnes, Perlusz Andrea (2009): Hatásértékelő tanulmány. A Nemzeti Fejlesztési Terv Humánerőforrás-fejlesztési Operatív Program 2.1.1 központi program Hátrányos helyzetü tanulók esélyegyenlőségének biztosítása az oktatási rendszerben „B” komponense (Sajátos nevelési igényü gyermekek együttnevelése) keretében kifejlesztett pedagógusképzési programok utóéletéröl. Educatio, Budapest.

Trencsényi László (szerk., 2009): Módszertár felsőfokon. Új Helikon Bt, Budapest.

UNESCO (1994): Salamancai nyilatkozat és cselekvési tervezet. ford. Schiffer Csilla. Letöltés ideje: 2006. 08. 30. http://www.barczi.hu/letoltesek/tudomanyos_testuletek/dokumentumok/SALAMANCAMagyar.pdf

UNESCO (2005): Guidelines for Inclusion: Ensuring Access to Education for All. UNESCO, Paris.

Vargáné Mező Lilla (2006): Inkluzív nevelés - Az integrált oktatás jogi háttere. Kézikönyv a pedagógusképző intézmények számára. SuliNova, Budapest.

Wocken, H. (2010): Integration \& Inklusion. Ein Versuch, die Integration vor der Abwertung und die Inklusion vor Träumereien zu bewahren. In: Stein, A. D. - Niediek, I. Krach, S. (Hrsg.): Integration und Inklusion auf dem Wege ins Gemeinwesen. Möglichkeitsräume und Perspektiven. Bad Heilbrunn, 204-234.

Zászkaliczky Péter, Lechta, V., Matuska, O. (szerk., 1999): A gyógypedagógia új útjai Rendszerfejlesztés, tanácsadás, integráció. BGGYTF, Budapest, 293-314. 